\title{
Corona Virus Pandemic and Way Forward
}

\author{
Sanaullah Sajid* and Sajjadur Rahman \\ Institute of Microbiology, University of Agriculture, Pakistan \\ *Corresponding author: Sanaullah Sajid, Institute of Microbiology, University of Agriculture, Pakistan
}

\begin{tabular}{|c|c|}
\hline ARTICLE INFO & Abstract \\
\hline Received: 幽 May 21, 2020 & \multirow{3}{*}{$\begin{array}{l}\text { Recent intervention of Corona virus into our life has created devastated social, } \\
\text { cultural economic and religious life on earth. Started from China, a novel strain of } \\
\text { Covid-19, changed the concept of Supremacy of mankind and invoke the word to } \\
\text { redefine the basis of humanity prevailing across the demographic boundaries of } \\
\text { nations. The sudden onset of Covid-19 calamity initiated a mindset change to think } \\
\text { about the real nature of mankind so vulnerable, sensitive, week and subtle. Such an } \\
\text { invisible creature of the creator has given us a chance to rethink the claim of superbeing } \\
\text { on the earth. This pandemic has initiated to rethink every individual of the word for } \\
\text { self-factualization. }\end{array}$} \\
\hline Published: May 26, 2020 & \\
\hline $\begin{array}{l}\text { Citation: Sanaullah S, Sajjadur R. Coro- } \\
\text { na Virus Pandemic and Way Forward. Bi- } \\
\text { omed J Sci \& Tech Res 27(5)-2020. BJSTR. } \\
\text { MS.ID.004570. }\end{array}$ & \\
\hline
\end{tabular}

\section{Opinion}

The framework of social norms stratification among various classes of mankind as created by the present leaders of the world as emphasized that such and invisible creature has no values and respect across the societies and sectarianism extra. Therefore, the moment has arisen to redefine the fabrics of society and norms for the wellbeing of every individual across the boundaries of the world. There have been so many cultures being observed by various Nations as a custodian of their plans and for the safeguard of their existence on the earth. This pandemic has initiated a new thinking about the cultural values in the face of invisible creature. The message is clear and loud that in the globalized world, the value of mankind can never be assessed through their culture they belong to. These cultural boundaries need to be redefined on the recent scenario where maximum benefit maybe extendable to the whole mankind throughout the world. The economic losses rendered by the pandemic has realized that the respect of mankind is supreme in the development of real sophisticated and progressive word. Covid-19 spread across the countries setting aside developed and underdeveloped Nations it is therefore time to realize that every individual life is counted and development in a true sense can never be restricted to few affluent people of the world.
Covid-19 pandemic made attention call to all the religions of the world to create conducive environment and extending the real benefits equal to every individual of the world instead of limiting the roots of religious benefits up to the believers and the angle of thought being learned that human values and right of living together cannot be ignored. The religious thinking should be extended to 360-degree angle for the benefits of the real essence of human beings on the earth. On one side this Coronavirus is smallest invisible creature has expressed its impact and the other side of the creator can never be neglected who has created the whole world full of beneficial behavior for the wellbeing of every individual on the earth. It is pertinent to explore the rapidly changing invisible creature under the continuous curtain of climate change whether it is natural or unnatural. The pandemic of Covid-19 has shocked the new concepts of incomplete, highly virulent and rapidly spreading nature of the creature which have the ability to conquer the whole world. It is the duty of every researcher and technologist to evolve new means and ways to protect the word from the emergence of such a covert enemy of mankind. 
ISSN: 2574-1241

DOI: 10.26717/BJSTR.2020.27.004570

Sanaullah Sajid. Biomed J Sci \& Tech Res

(C) This work is licensed under Creative

Submission Link: https://biomedres.us/submit-manuscript.php

$\begin{array}{ll}\text { BIOMEDICAL } & \text { Assets of Publishing with us } \\ \text { RESEARCHES } & \text { - Global archiving of articles } \\ & \text { - Immediate, unrestricted online access } \\ & \text { - Rigorous Peer Review Process } \\ & \end{array}$

